\title{
Consumption Pattern of Timber and Fuelwood in Community Forests: a case study from Sindhupalchok District
}

\author{
D. Lamichhane ${ }^{1}$
}

\begin{abstract}
The study was carried out in four community forest user groups (CFUGs) of Sindhupalchok district of Nepal with a view to find out the consumption pattern of forest products especially timber and fuelwood from the community forests (CFs). A set of structured questionnaires was used to collect data from the respondents of the selected CFUGs. Four CFUGs were randomly selected from among those meeting the predetermined criteria such as: more than 5 years old, regularly harvesting timber and fuelwood, and active in forest management. With a 20\% sampling intensity, 103 respondents were identified from the groups for household visit and personal interview. Records of forest product distribution together with a checklist of secondary data were obtained from the District Forestry Office (DFO) and the CFUG records. This data were analyzed using both descriptive and inferential statistical analysis. Results indicated that there was no significant difference in the use of timber and fuelwood among the users. Similarly, there was no correlation between the number of livestock and use of firewood. However, there was a strong relationship between the number of livestock and fodder trees on their farmland. There was a higher demand for fuelwood than timber but the pine-dominant community forests were found to be producing more timber, thereby creating a big gap between the demand and supply of firewood. However, the supply of timber was comparatively consistent with demand.
\end{abstract}

Keywords: Community forest user group, demand and supply, farmland, fuelwood, timber

O ne of the long-term objectives of Community Forestry Programme was to regularize supply of the people's basic needs for timber, fuelwood, fodder and other forest products (MFSC, 1988). Considering the rural population of Nepal, 67 percent of the energy requirement was met through firewood (DoF, 1995). Community forestry was clearly contributing to rural peoples' livelihoods, through the acquisition of resources from forest products and other sources (Pearce et al. 2003). Our future challenge is to enhance the productivity of $\mathrm{CF}$, and to ensure the equitable distribution of its benefits through the transformation of natural resources into assets that can address the livelihood priorities of CFUGs, particularly those of the poorest (Allison et al., 2004). The user groups receiving official support have substantially improved the condition of their CFs, for example by way of reducing forest fire occurrence (Tachibana \& Adhikari, 2009).

Nevertheless, the current practices of community forest management have, to some extent, negative impacts on the rural poor that lack the provisions for addressing equitable system of benefit distribution and cost sharing among the forest user groups and households. If community forestry is to be rural poor-friendly, poor-income households should be able to realize the full value of the share of unused forest products either by way of transferable rights or from access to markets (Dahal, 2006). According to Dahal (2006), the net benefit and benefit-cost (B-C) ratios for the three income groups were calculated with the help of summary statistics of gross benefits and costs. The net benefit and B-C ratios for poor, medium and rich households were found to be $-3,0.85$, and $0 ; 1,4$, and 1.08 , respectively. In his study, eight major types of forest products from CFs were considered as material values. The total costs of forest use and management were broken down into labor costs, transaction costs and membership fees.

The access of poor people to resources and capital has been reduced, with consequent negative impacts on their livelihoods (Ostrom, 1990). This reduced 
access has forced the poorest to enter nearby forests (other than $\mathrm{CFs}$ ) which in turn has increased travel time for them to collect the forest products and induced negative impact on the condition of government forests in the neighboring areas. On the other hand, this situation reflects weak CFUG-level governance (Pokharel \& Niraula, 2004). Increased growing stock of CF does not necessarily mean that there is increased access to either timber or fuelwood. Although the operational plans require a complex exercise of calculating the growing stock, annual increment and annual allowable cut as part of the operational plan preparation. Currently, even under CF-management practices, the only timber and fuel that can be harvested are from trees that have fallen down from natural causes or from allowable forest practices, such as thinning.

This study was intended to carry out a district-level survey regarding the utilization pattern of timber and fuelwood collected from the CFs. The specific objectives of the study were to: (i) collect the socioeconomic information of the forest users using forest products; (ii) estimate the annual extraction of timber and fuelwood from the community forests of the district; and (iii) identify the household consumption and sale and the main uses of the forest products.

Four community forests of Sindhupalchok district of the Central Development Region of Nepal (Figure 1) were selected. The forests here were mostly pinedominated, consisting of the plantations done by the then Nepal-Australia Community Forestry Project.

This study has helped elaborate the utilization pattern of forest products such as timber and fuelwood extracted from the CFs in Sindhupalchok district of the Central Development Region of Nepal. The utilization pattern includes the data on the demand and supply condition of timber and fuelwood in the district and quantitative basis for comparison with other community forests.

\section{Materials and Methods}

The study area covered four CFUGs viz. Bhagwati, Gaurati, Jogikhoriya and Sunkoshi. Using the CFUGdatabase available in the District Forest Office (DFO), the aforementioned four CFs were selected randomly among those meeting some predetermined criteria such as the CFs with trees more than 5 years old, the CFs producing timber and fuelwood, and the $\mathrm{CFs}$ active in forest management. Altogether, 103 sets of questionnaire and 80 sets of checklist were used for primary data collection.

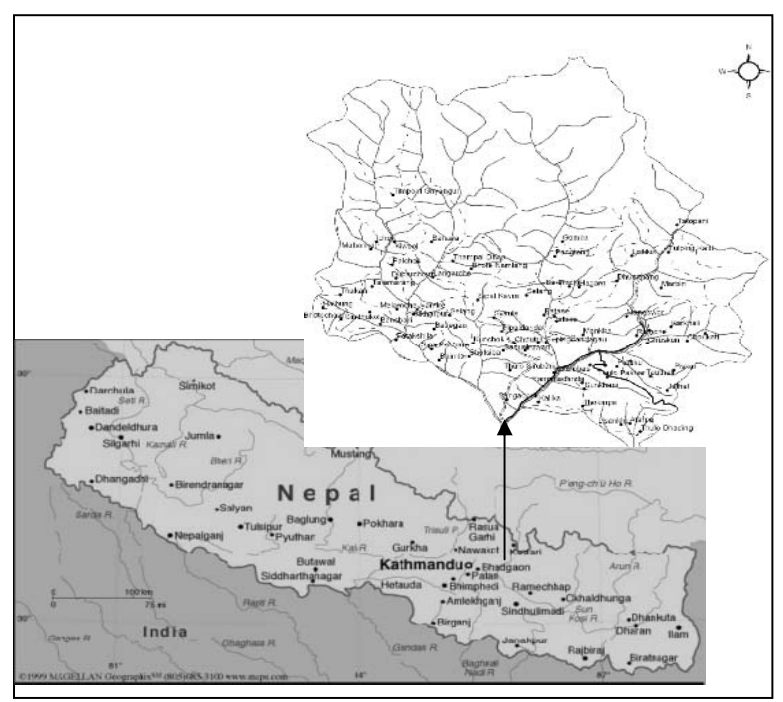

Figure1: Map of the study Area

With 20 percent sampling intensity, 103 respondents were selected from the groups for household visit and personal interview. 20 percent of these respondents were female. Primary data were collected using a number of techniques namely, household survey, focus-group discussion using PRA/RRA method, and a checklist for key informants. On the other hand, District and CFUG records of forest products distribution and a checklist for committee member were used for the collection of secondary data which included database of the DFO, operational plan and records of the CFUGs and other published and unpublished sources relevant to the survey. Both primary and secondary data were organized and entered into a computer program for statistical analysis. The data were analyzed with the help of both descriptive and inferential statistical analysis such as tables, graphs, correlation analysis and Chi-square (Ç2) test. The demand and supply of forest products and their consumption was assessed using socioeconomic data.

\section{Results and Discussions}

\section{Existing demand \& supply situation of timber and fuelwood}

According to the DFO record of the Fiscal Year 063/64 (2006-07), the consumption quantities within the selected four CFUGs were: fuelwood - 102,064 metric tons, timber - 1,013,580 cubic feet and others $-122,438$ metric tons. Similarly, timber and fuelwood 
sale outside the CFUGs was 13,359.39 cubic feet and 1,200 kilograms respectively. The consumption pattern within the CFUGs was determined by multiplying the average household consumption figure with the total number of households surveyed (DFO, 2006).

The supply curve for timber and fuelwood harvested from any CF is normally vertical because both the quantity supplied as well as the price are generally fixed. The harvests of the forest products from the mentioned CFs will be also have a vertical supply curve. No matter how much someone would be willing to pay for additional products; extra timber/ fuelwood cannot be produced as the annual allowable harvest is set by the operational plan. Also, even if no one wants the products, the allowable cut will still be made. Since the supply $\mathrm{S}$ and price $\left(\mathrm{P}_{1}\right)$ are fixed for timber \& fuelwood, any shift in demand will only create gap between $\mathrm{D}_{1}$ and $\mathrm{D}_{2}$ (Figure 2).

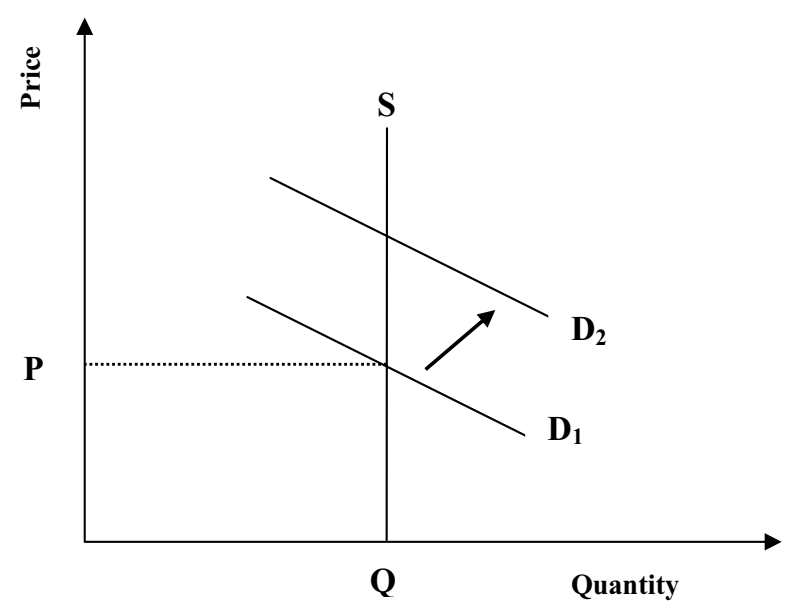

Figure 2: Theoretical Demand \& Supply curve

When the demand $\mathrm{D}_{1}$ is in effect, the price will be $\mathrm{P}_{1}$. Similarly, when the demand $\mathrm{D}_{2}$ occurs, the price should go up but because of the fixed price, it will still remain at $\mathrm{P}_{1}$. Notice that at both values, the quantity is $\mathrm{Q}$. Here, $\mathrm{Q}=$ forest products available for annual harvest as per the annual allowable harvest prescribed in the operational plan. Demand of fuelwood/timber generally increases because of population growth, separation of family/household, poverty and so on.

\section{Production and distribution of timber \& fuelwood}

There was higher demand of fuelwood than timber (figure 3). The main forest products of these pinedominated forests were fuelwood and timber. Harvesting of the products was done according to

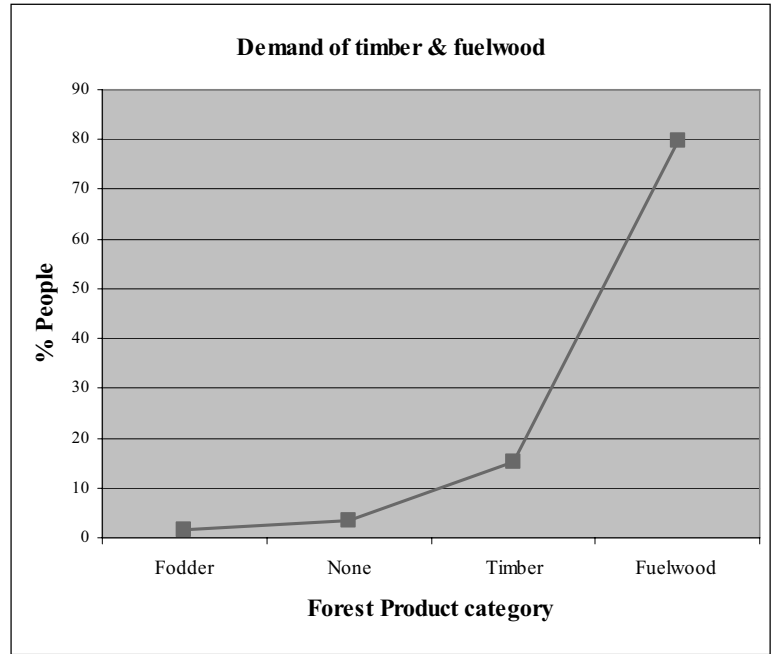

Figure 3: Demand status of forest products

the operational plan, i.e. taking out the forest products from 1-2 blocks rotationally. Generally, the CFUGs have prioritized the distribution of timber to the users in the case of: (i) construction of house for the households affected from natural hazards (flood, landslide and fire); (ii) making agricultural tools (plow, yoke, and handles of various tools); (iii) building new house in the case of separation within families; (iv) repairing the houses; (v) building and repairing cattle sheds; and (vi) public construction and developmental activities. In all these cases, poor and disadvantaged groups were said to have preference. Timber to make charcoal was free for blacksmith during harvesting period. In some cases, transportation cost of forest products was so high that users were unwilling to collect fuelwood.

\section{Consumption of fuelwood and its utility}

Fuelwood was mostly utilized for brewing local alcohol readily saleable in the market; the users did not hesitate to use even timber as fuelwood. This indicates the users' preference for fuelwood over timber and their higher utility. For making local wine, they bought timber at high price and used it as fuelwood. So there was the provision in the rule that ensured the use of timber only as timber and not as fuelwood. The timber from CFUGs was not allowed to be sold at local sawmills. Timber species most in demand were Chilaune (Schima wallichii) followed by Sallo (Pinus spp.). Therefore, the CFUGs wanted to convert their pine forests to broadleaved ones. However, fuelwood was adequate for those users who did not brew local alcohol.

Some of the measures to reduce fuelwood consumption included use of improved stove, biogas 
Table 1: Measures taken to reduce fuelwood consumption

\begin{tabular}{lcccc}
\hline \multirow{2}{*}{ CFUG } & \multicolumn{2}{c}{ Yes (\%) } & \multirow{2}{*}{ Both (\%) } & \multirow{2}{*}{ No (\%) } \\
\cline { 2 - 3 } & Improved Stove & Kerosene and Gas & & 66 \\
\cline { 2 - 4 } Bhagwati & 28 & 6 & 34 & 45 \\
Gaurati & 40 & 15 & 55 & 60 \\
Jogikhoriya & 15 & 25 & 40 & 10 \\
Sunkoshi & 30 & 60 & 90 & 6 \\
\hline
\end{tabular}

Table 2: Measures to substitute insufficient timber \& fuelwood from CF $(n=103, p=0.05)$

\begin{tabular}{|c|c|c|c|c|c|c|}
\hline \multirow{2}{*}{ CFUG } & \multicolumn{3}{|c|}{$\begin{array}{c}\text { Percentage of users using } \\
\text { timber/fuelwood }\end{array}$} & \multirow{2}{*}{$\begin{array}{l}\text { Percentage of } \\
\text { people using } \\
\text { kerosene and } \\
\text { gas } \\
\end{array}$} & \multirow[t]{2}{*}{$\chi^{2}$ value } & \multirow[t]{2}{*}{ Significance } \\
\hline & CF & Farmland & Buying & & & \\
\hline Bhagwati & 16 & 72 & 12 & 0 & \multirow{4}{*}{88.38} & \multirow{4}{*}{ Significant } \\
\hline Gaurati & 34 & 66 & 0 & 0 & & \\
\hline Jogikhoriya & 40 & 60 & 0 & 0 & & \\
\hline Sunkoshi & 0 & 0 & 66 & 34 & & \\
\hline
\end{tabular}

plant, raising fewer quality-cattle than more quantity cattle, grass production on risers, terrace and marginal lands. According to the users, the production of timber and fuelwood from their CFs was insufficient for their needs and so, additional timber and fuelwood had to be purchased from other CFs and outside to meet their demands. Sometimes, they even fetched forest products illegally from other CFs and government forests.

Apart from the CFs, there were 48 private forests registered at the District

Forest Office (DFO). The CFUGs did not have any program for reducing fuelwood consumption. The trees included in agroforestry practices on farmlands were mainly Kutmiro (Litsea monopetala), Chilaune along with Sal (Shorea robusta) and Sallo. Initially, the consumption of Chilaune for fuelwood was high but with their declining availability, the fuelwood demand has shifted to pines. Now pines are thinned to promote succession by Chilaune to a broadleaf forest again. Pines continue to grow faster on gentle slopes while Uttis and Chilaune were grown on eroded areas.
To make up for the insufficient forest products, the users had to depend mostly on their own farmlands. Possibility of biogas for fuel energy was unlikely due to the lack of livestock (sheep/goat, cattle and buffalo). The Ç2 test demostrated the significant differences on the sources of fuel energy used to make up for declining timber and fuelwood from the CFs (Table 2).

The major species grown in the farmlands include Kutmiro, Utis, Tooni (Cedrela toona), Kyamun (Syzizium cumini), Badahar (Artocarpus lakoocha), Khanyu (Ficus semicordata), Lapsi (Choerospondias axillaris), Aamp (Mangifera indica) and Sallo. The main timber species on the farmlands was Chilaune.

The average livestock per households was 4 (Table $3)$. Similarly, the average number of trees per household was found to be 27.25 whereas average number of fodder trees in the farmland was 9.25. Table 3 indicates the correlation between the number of livestock and fodder trees in private land.

Since, $|r|>6 \times$ P.E., there is significant relationship between number of livestock and number of fodder trees in their farmland.

Table 3: Correlation between the number of livestock and fodder trees

\begin{tabular}{lcrrr}
\hline \multicolumn{1}{c}{ CFUG } & $\begin{array}{c}\text { Average no. of } \\
\text { livestock/house- } \\
\text { hold }\end{array}$ & $\begin{array}{c}\text { Average no. of } \\
\text { trees/households }\end{array}$ & $\begin{array}{c}\text { Average no. of } \\
\text { fodder } \\
\text { trees/households }\end{array}$ & $\begin{array}{c}\text { Correlation } \\
\text { Coefficient }\end{array}$ \\
\hline Bhagwati & 6 & 39 & 13 & \\
Gaurati & 5 & 34 & 12 & $(\mathbf{r})=\mathbf{0 . 9 8}$ \\
Jogikhoriya & 3 & 22 & 5 & \\
Sunkoshi & 2 & 14 & $\mathbf{9 . 2 5}$ & \\
Av./household & & $\mathbf{4}$ & $\mathbf{2 7 . 2 5}$ & \\
\hline
\end{tabular}

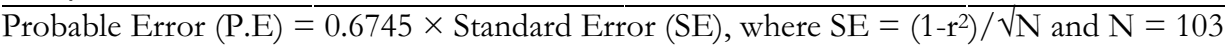




\section{Consumption pattern of timber and fuelwood in CFUG}

Timber was a major product of the CFs since the plantation-forests of pines were grown to produce enough timber. Timber was mainly used for constructional activities, but most of the users also burned timber due to the scarcity of fuelwood. Although the CFUGs had accorded priority to the needy users for the maintenance and construction of their houses and cowsheds, a substantial number of users had no need for timber. The Ç2 value revealed that use of timber was not significantly different among the CFUGs (Table 4).

Similarly, fuelwood was mostly used for cooking food, followed by large amounts of fuelwood used to brew local alcohol. Local alcohol was one of the main sources of income as it was readily saleable. The use of fuelwood for different purposes was found to be insignificant among the CFUGs, according to Chi square test below (Table 5).

\section{Conclusions}

Fuelwood and timber were found to be the major forest products in the study area. Results revealed that the forest product most in demand was fuelwood and that its supply was insufficeint for many users since additional fuelwood was needed to brew alcohol as a source of ready cash income. The CFUGs did not have many measures to meet their shortfall in fuelwood demands. Trees on farmlands were relatively few and other fuel energies such as biogas were not viable due to inadequate livestock numbers. Users with insufficient fuelwood from small CF or their farm trees had to buy them from elsewhere, or fetch them from other CFs or government forests. Participation of users in forest management activities was poor because of the lack of time as labour was the main source of income for many users. Therefore, most activities of CF management were carried out on wage basis. The consumption patterns for timber and fuelwood by the users were not significant among the CFUGs but the measures taken by the users to complement the under-supplied fuelwood were significantly different.

Table 4: Consumption pattern of timber

\begin{tabular}{|c|c|c|c|c|c|c|}
\hline \multirow[b]{2}{*}{ CFUG } & \multicolumn{4}{|c|}{ Percentage of users vs. consumption pattern of timber } & \multirow{2}{*}{$\begin{array}{c}\chi^{2} \\
\text { value }\end{array}$} & \multirow[b]{2}{*}{ Significance } \\
\hline & $\begin{array}{c}\text { House } \\
\text { construction }\end{array}$ & $\begin{array}{c}\text { Cowshed } \\
\text { construction }\end{array}$ & Both & No use & & \\
\hline Bhagwati & 64 & 16 & 12 & 8 & \multirow{4}{*}{15.53} & \multirow{4}{*}{ Not significant } \\
\hline Gaurati & 58 & 12 & 30 & 0 & & \\
\hline Jogikhoriya & 40 & 15 & 15 & 30 & & \\
\hline Sunkoshi & 35 & 10 & 30 & 25 & & \\
\hline
\end{tabular}

$\mathrm{n}=103$ and $p=0.05$

Table 5: Use of fuelwood $(\mathrm{n}=103, p=0.05)$

\begin{tabular}{|c|c|c|c|c|c|c|}
\hline \multirow[b]{2}{*}{ CFUG } & \multicolumn{4}{|c|}{ Use of Firewood (\% people) } & \multirow[b]{2}{*}{$\begin{array}{c}\chi^{2} \\
\text { value }\end{array}$} & \multirow[b]{2}{*}{ Significance } \\
\hline & $\begin{array}{l}\text { Cooking and } \\
\text { making coal }\end{array}$ & $\begin{array}{l}\text { Cooking and } \\
\text { making alcohol }\end{array}$ & $\begin{array}{l}\text { Cooking } \\
\text { food only }\end{array}$ & $\begin{array}{l}\text { Cooking food } \\
\text { and kundo* }\end{array}$ & & \\
\hline Bhagwati & 24 & 4 & 44 & 28 & & \\
\hline Gaurati & 8 & 27 & 27 & 38 & 13.47 & Not significant \\
\hline Jogikhoriya & 20 & 20 & 10 & 50 & & \\
\hline Sunkoshi & 15 & 20 & 35 & 30 & & \\
\hline
\end{tabular}

* Kundo is a foodstuff cooked for cattle using maize, millet, rice etc. 


\section{References}

Allison, G., Bampton, J., Kandel B.R., Shrestha, M.L. and Shrestha N.K. 2004. Community Forestry and Livelihoods: How can Community Forestry Better Contribute to the Millennium Development Goals? In Twenty-five Years of Community Forestry. Proceedings of the Fourth National Workshop on Community Forestry, 46 August, 2004, Kathmandu, Nepal. (eds.) Kanel, K. R. et al. Department of Forest, December 2004, 171-179.

Dahal, Mahesh R. 2006. Benefit-cost analysis of community forest and its distributional impact on rural poor. Economic Journal of Nepal, 29 (2): 93-107.

DoF. 1995. Community Forestry Manual. Department of Forest, Kathmandu, Nepal.

MFSC. 1988. Master Plan for the Forestry Sector of Nepal. Ministry of Forests and Soil Conservation, His Majesty's Government of Nepal, Kathmandu.
Ostrom, E. 1990. Governing the Commons: The Evolution of Institutions for Collective Action. Cambridge University Press.

Pearce, D., Putz, F.E. and Vanclay, J.K. 2003. Sustainable forestry in the tropics: panacea or folly? Forest Ecology and Management, 172 (2-3): 229247.

Pokharel, B.K. and Niraula D.R. 2004. Community forestry governance in Nepal: achievements, challenges and options for the future, 2004. In Twenty-five years of Community Forestry. Proceedings of the fourth national workshop on community forestry, 4-6 August, 2004, Kathmandu, Nepal. (eds.) Kanel, K. R., et al. Department of Forest, December 2004, 298-316.

Tachibana, T. and Adhikari, S. 2009. Does community-based management improve natural resource condition? Evidence from the Forests in Nepal. Land Economics, 85(1):107-131. 